\title{
FAKTOR YANG MEMPENGARUHI KINERJA PERAWAT DALAM PELAKSANAAN PROSES KEPERAWATAN
}

\author{
Ade sulistya lubis/181101121 \\ Adesulistyalubis@gmail.com
}

\begin{abstract}
Abstrak
Latar belakang: Jurnal ini bertujuan menganalisis factor yang mempengaruhi kinerja perawat dalam pelaksanaan proses keperawatan. Tujuan: Untuk mengetahui factor pengaruh kinerja perawat dalam pelaksanaan proses keperawatan. Metode: Jurnal ini menggunakan metode tersearch dan analisis dari berbagai sumber seperti buku teks, buku referensi jurnal dan e-book, dan juga membandingkan beberapa jurnal yang berhubungan dengan factor yang mempengaruhi kinerja perawat dalam pelaksanaan proses keperawatan. Hasil : Hasil penulisan jurnal ini diketahui bahwa kinerja perawat dalam pelakasaan proses keperawatan dapat dipengaruhi oleh beberapa factor yaitu motivasi, pengembangan karir, supervise dan pendapatan/gaji.. Kesimpulan : Hasil penulisan jurnal ini adalah Peningkatan kinerja perawat dalam pelaksanaan proses keperawatan melalui dukungan dari pemerintah terkait dengan mengalokasikan anggaran terhadap jasa perawat dalam pendokumentasian proses keperawatan serta mengadakan pelatihan kepada perawat yang bertugas di Rumah Sakit, sehingga pelayanan keperawatan lebih maksimal dan dapat memberikan kepuasan kepada masyarakat.
\end{abstract}

Kata kunci: kinerja perawat, pelaksanaan, proses keperawatan

\begin{abstract}
Background: This journal aims to analyze the factors that influence nurses' performance in implementing the nursing process. Objective: To find out how the nurse's performance influences the implementation of the nursing process. Method: This journal uses the search method and analysis from various sources such as textbooks, journal reference books and e-books, and also compares several journals related to factors that influence the performance of nurses in the implementation of the nursing process. Results: The results of writing this journal are known that the performance of nurses in the implementation of the nursing process can be influenced by several factors, namely motivation, career development, supervision and income / salary. Conclusion: The results of writing this journal are Improving the performance of nurses in the implementation of the nursing process through support from the government related to allocating a budget for nurse services in documenting the nursing process and conducting training for nurses on duty at the hospital, so that nursing services are more maximized and can provide satisfaction to the community.
\end{abstract}

Keywords: nurse performance, implementation, nursing proces 


\section{PENDAHULUAN}

\section{LATAR BELAKANG}

Berdasarkan Undang-Undang Republik Indonesia Nomor 23 Tahun 1992 tentang Kesehatan, bahwa untuk mewujudkan derajat kesehatan yang optimal bagi masyarakat diadakan upaya kesehatan mencakup upaya peningatan kesehatan (promotif), pencegahan penyakit (preventif), penyembuhan penyakit (kuratif) dan pemulihan kesehatan (rehadolitatif) yang dilaksankan secara menyeluruh, terpadu, dan berkesinmabungan dan dilaksanakan bersama antara pemerintah dan masyarakat yang didukung oleh sumber daya kesehatan termasuk tenaga kesehatan.

Gronross dalam Kotler (1997) mengatakan bahwa ada tiga unsur pokok yang saling berinteraksi dalam masalah mutu pelayanan terhadap kinerja yaitu pelanggan (customer), petugas pelayanan (customer service) dan manajeman (management). Salah satu hal yang penting dalam mencapai mutu pelayanan ialah kinerja petugas pelayanan dalam proses interaksi dengan pelanggan (pasien). Interaksi antara petugas dengan pasien merupakan hal yang sangat mendalam yang dirasakan pasien saat menerima pelayanan. Proses ini sangat dipengaruhi oleh perilaku petugas dalam melaksanakan pelayanan.

Perbaikan mutu di rumah sakit melalui kinerja pelayanan kepada pasien pada umumnya dimulai oleh perawat melalui berbagai bentuk kegiatan, seperti gugus kendali mutu, penerapan standar asuhan keperawatan, pendekatan-pendekatan pemecahan masalah, maupun peningkatan kinerja keperawatan. Laporan ini dilakukan dengan menggunakan pendekatan proses keperawatan.

Proses keperawatan adalah suatu metode yang sistematis untuk mengkaji respon seorang pasien terhadap masalah-masalah kesehatan dan membuat rencana keperawatan yang bertujuan untuk mengatasi masalah-masalah tersebut. Proses keperawatan didokumentasikan sebagai asuhan keperawatan (Potter \& Perry, 2009).

Dokumentasi asuhan keperawatan mencakup pernyataan dan pelaporan tentang pengkajian (pengumpulan data), diagnosis keperawatan, rencana tindakan keperawatan, tindakan dan evaluasi keperawatan.Dokumentasi yang efektif menjamin kesinambungan pelayanan, 
menghemat waktu, dan meminimalisasi resiko kesalahan (Potter \& Perry, 2009).

\section{TUJUAN}

1. Tujuan umum

Untuk mengetahui factor yang mempengaruh kinerja perawat dalam pelaksanaan proses keperawatan.

2. Tujuan khusus

a. Mengetahui bagaimana kinerja perawat dalam pelaksanan proses keperawatan.

b. Mengetahui hubungan factor yang mempengaruhi kinerja perawat dalam pelaksanaan proses keperawatan .

\section{METODE}

Jurnal ini menggunakan metode tersearch dan analisis dari berbagai sumber seperti buku teks, buku referensi jurnal, e-book, dan juga membandingkan beberapa jurnal yang berhubungan dengan factor yang mempengaruhi kinerja perawat dalam pelaksanaan proses keperawatan. Dari analisi berbagai sumber digunakan Untuk mengetahui factor pengaruh kinerja perawat dalam pelaksanaan proses keperawatan. Penulisan jurnal ini dimulai pada tanggal 21 september2019. Pengolahan jurnal dilakukan dengan metode membandingkan beberapa jurnal yang berhubungan dengan factor yang mempengaruhi kinerja perawat dalam pelaksanan proses keperawatan.

\section{HASIL}

Hasil dari pembandingan jurnal (NERS Jurnal Keperawatan Volume 10, No 1, Maret 2014 : 21-27 ) penulis dapat mengetahui factor apa saja yang dapat mempengaruhi kinerja perawat. Ada beberapa factor yang dapat mempengaruhi kinerja perawat yaitu motivasi, pengembangan karir, supervise dan pendapatan/gaji.

Kinerja (prestasi kerja) adalah hasil kerjasama kualitas dan kuantitas yang dicapai oleh seorang pegawai dalam melaksanakan tugasnya sesuai dengan tanggung jawab yang diberikan kepadanya. Kinerja atau performace adalah hasil kerja yang dapat dicapai oleh seseorang atau kelompok yang dalam suatu organisasi sesuai dengan kewenangan dan tanggung jawab masing- masing dalam rangka upaya mencapai tujuan oganisasi bersangkutan, secara legal, tidak melanggar hukum dan sesuai dengan norma dan etika.

Tenaga perawat yang mempunyai motivasi tinggi, karena merasa bahwa kebutuhannya 
telah terpenuhi sehingga terdorong untuk lebih giat melaksanakan tugasnya. Motivasi berkaitan erat dengan dorongan yang kuat untuk melakukan setiap pekerjaan dengan hasil yang optimal.

Faktor-faktor seperti kepuasan terhadap gaji dan insentif yang diterima, kedudukan dan kondisi lingkungan kerja yang kondusif akan mendorong tenaga perawat untuk bekerja lebih baik sehingga kinerjanya lebih baik pula. Berbeda dengan yang tidak memiliki motivasi tinggi maka ia tidak memiliki hasrat untuk berkerja semaksimal mungkin serta bersikap apatis terhadap tugasnya yang mengakibatkan kinerjanya kurang baik. Kopelman (1986) mengemukakan bahwa pendapatan/gaji akan berpengaruh untuk meningkatkan motivasi kerja yang pada ahirnya secara langsung akan meningkatkan kinerja individu.

Perawat sebagai suatu profesi harus dapat mempertahankan dan meningkatkan mutu asuhan keperawatan dengan standar. Standar merupakan level kinerja yang diinginkan dan dapat dicapai dimana kerja aktual dapat dibandingkan. Ia memberikan petunjuk kinerja mana yang tidak cocok atau tidak dapat diterima. Standar praktek keperawatan adalah pernyataan tentang apa yang dibutuhkan oleh registered nursed untuk dijalankan sebagai profesi keperawatan. Secara umum standar ini mencerminkan nilai profesi keperawatan dan memperjelas apa yang diharapkan profesi keperawatan dari para anggotanya.

\section{PEMBAHASAN}

Dari hasil pembandingan beberapa jurnal penulis dapat menguraian bahwa kinerja perawat sangat memegang peranan penting dalam meningkatkan mutu pelayanan keperawatan menuju pelayanan prima dan lebih khusus lagi untuk meningkatkan kinerja keperawatan di rumah sakit.

(Jurnal e-Biomedik (eBm), Volume 3, Nomor 3, September-Desember 2015) mengatakan bahwa kinerja perawat dalam pelaksanaan proses keperawatan merupakan indikator mutu pada suatu rumah sakit. Penelitian ini bertujuan untuk mengetahui hubungan antara motivasi, kompetensi, supervise dan penghargaan dengan kinerja perawat dalam pelaksanaan proses keperawatan.

Motivasi yang dimiliki perawat dilihat dari hasil observasi adalah baik, perawat melakukan tugas dengan cepat tanggap dan terlihat bersemangat, dari kinerja yang dilakukan perawat terlihat baik didukung 
dengan peneliti mewawancarai pasien tentang kinerja perawat, pasien mengatakan puas dengan pelayanan yang diberikan perawat dan pasien mengatakan secara umum pelayanan kinerja perawat dirumah sakit ini baik, dengan seringnya dilakukan evaluasi dirumah sakit ini menunjukkan tugas perawat terkontrol dan terarah. Motivasi merupakan perasaan atau pikiran yang mendorong seseorang melakukan pekerjaan atau menjalankan kekuasaan terutama dalam berperilaku agar seseorang dapat memenuhi kebutuhan dan keinginanya tidaklah mudah didapat apabila tanpa usaha yang maksimal. Dalam memenuhi kebutuhanya seseorang akan berperilaku sesuai dengan dorongan yang dimiliki dan apa yang mendasari perilakunya, dengan demikian dapat dikatakan bahwa dalam diri seseorang ada kekuatan. Motivasi yang memberikan kekuatan seseorang berperilaku dapat berasal dari interen ataupun eksteren. Teori motivasi memberikan penjelasan tentang kebutuhan dan keinginan seseorang serta menunjukan arah tindakannya.

Motivasi yang juga merupakan kondisi dari perawat tersebut yang bisa mendorong seorang perawat untuk berperilaku menuju tujuan yang ingin dicapainya. Motivasi juga bisa membuat seorang perawat untuk memprediksi perilaku apa yang akan dilakukan. Dalam hal ini perilaku darperawat akan baik berasal dari motivasi perawat yang memang baik. Jadi apabila seorang perawat memiliki motivasi yang baik untuk mencapai tujuannya, maka kinerja akan meningkat. Meningkatnya kinerja perawat, dalam penelitian ini menyangkut asuhan keperawatan, akan meningkat pula kinerja rumah sakit tersebut. Dengan demikian, makin meningkatnya motivasi perawat secara individu akan meningkatkan kinerja individu, kelompok maupun rumah sakit tersebut.

Laporan ini dilakukan dengan menggunakan pendekatan proses keperawatan. Proses keperawatan adalah suatu metode yang sistematis untuk mengkaji respon manusia terhadap masalah-masalah kesehatan dan membuat rencana keperawatan yang bertujuan untuk mengatasi masalah-masalah tersebut. Proses keperawatan didokumentasikan sebagai asuhan keperawatan (Potter \& Perry, 2009). 
Dokumentasi asuhan keperawatan mencakup pernyataan dan pelaporan tentang pengkajian (pengumpulan data), diagnosis keperawatan, rencana tindakan keperawatan, tindakan dan evaluasi keperawatan.Dokumentasi yang efektif menjamin kesinambungan pelayanan, menghemat waktu, dan meminimalisasi resiko kesalahan (Potter \& Perry, 2009).

Dokumentasi asuhan keperawatan yang baik dan berkualitas haruslah akurat, lengkap dan sesuai standar.Apabila asuhan keperawatan tidak didokumentasikan dengan akurat dan lengkap maka sulit untuk membuktikan bahwa asuhan keperawatan telah dilakukan dengan benar (Hidayat dalam Sari, 2012). Pendokumentasian asuhan keperawatan merupakan suatu proses yang harus dilaksanakan oleh perawat pelaksana sebagai bagian dari standar kerja yang telah ditetapkan (Nursalam, 2007).

\section{PENUTUP}

\section{KESIMPULAN}

Berdasarkan hasil pembandingan dari beberapa jurnal penulisan dapat menyimpulkan bahwa Peningkatan kinerja perawat dalam pelaksanaan proses keperawatan melalui dukungan dari pemerintah terkait dengan mengalokasikan anggaran terhadap jasa perawat dalam pendokumentasian proses keperawatan, serta melaksanakan proses keperawatan di Rumah Sakit, sehingga pelayanan keperawatan lebih maksimal dan dapat memberikan kepuasan kepada masyarakat.

\section{SARAN}

Bagi mahasiswa perawat diharapkan untuk mengembangkan pembandingan jurnal ini dan menjadikan budaya baca riset-riset keperawatan baik nasional maupun internasional sebagai penambahan ilmu pengetahuan dan kebutuhan bagi mahasiswa perawat pelaksana serta selalu mengasah dan melatih kinerja perawat dalam pelaksanaan proses keperawatan.

Diharapkan hasil pembandingan jurnal ini dapat dikembangkan oleh penulis lain dengan menggunakan variabel-variabel lain yang berpengaruh terhadap kinerja perawat dalam pelaksanaan proses keperawatan. 


\section{REFERENSI}

Afandi, (2013). Hubungan Beban Kerja

Dengan Kinerja Perawat di RSUD

Saras Husada Purworejo:

Universitas Muhammadya

Yogyakarta.

Badi'ah., A., dkk., (2008). Hubungan Motivasi Perawat Dengan Kinerja Perawat Diruang Rawat Inap RSD Panembahan Senopati Bantul. jurnal.ugm.ac.id/jmpk/article/dow nload/2555/2289 diakses tangggal 5 oktober 2014.

Batuah, N., (2012). Hubungan Beban Kerja Perawat Terhadap Kinerja Perawat Pelaksana Dalam Pemberian Pelayanan Kesehatan DI Ruang Rawat Inap Rumah Sakit Islam Faisal Makasar. Jurnal Keperawatan STIKES Nani Hasanuddin MakassarDepkes, RI. (2001). Tenaga Kesehatan Tentang Kualitas Pelayanan, Bina Diknaskes Edisi 27, Jakarta.

Elisabeth Manuho dkk, Hubungan Beban Kerja Dengan Kinerja PerawatDalam Pemberian Asuhan Keperawatan Di
Instalasi Rawat Inap C1 Rsup Prof. Dr. R. D. Kandou Manado. ejournal Keperawatan (e-Kep) Volume 3.Nomor 2,Mei2015.

Fitra Yeni: Pengaruh Pelatihan Proses Keperawatan terhadap Dokumentasi Asuhan Keperawatan di Puskesmas Kabupaten Agam Propinsi Sumatera Barat. NERS Jurnal Keperawatan Volume 10, No 1, Maret $2014: 21-27$.

HamsinahST,KamalA,HaskasY.Hubungn antara Sistem Penghargaan dengan Kinerja Perawat dalam Melaksanakan Asuhan Keperawatan di Unit Pelayanan TekhnisDaerah $R S U$ Sayang Rakyat. Jurnal STIKES.Nani.Hasannudin.201 3;3(4):13-50.

Husnah, A. R. (2019).berpikir kritis perawat dalam pengaplikasian caring. Osfyo

Kartin Buheli. Faktor Yang Mempengaruhi Kinerja Perawat Dalam Penerapan 
Proses Keperawatan di RSUD

Toto Kabupaten Bone Bolango.

Jurnal e-Biomedik(eBm),

Volume 3,Nomor 3, September-

Desember 2015.

Simamora, R. H. (2019). Menjadi perawat yang: CIH'HUY. Surakarta: kekata Publisher.

L.M.Harmain Siswanto dkk, FaktorFaktor Yang Berhubungan Dengan Kelengkapan Pendokumentasian Asuhan Keperawatan. Jurnal Keperawatan Indonesia, Volume 16 No.2, Juli 2013, hal 77-84 pISSN 1410-4490, eISSN 2354-9203.

Musta'an,HaryantiS.Hubunngan antara Motivasi dengan Kinerja Perawat ditinjau dari Dokumentasi Asuhan Keperawatan di RS Paru Dr. Ario Wirawan Salatiga. Jurnal Ilmu Keperawatan Indonesia.2010;1(1):12.

MulyonoHM, Hamzah A, AbdullahAZ. Faktor Yang Berpengaruh Terhadap Kinerja Perawat Di Rumah Sakit Tingkat III 16.06.01
Ambon .Jurnal AKK. 2013;2(1):18-26.

Potter, P. A., \& Perry, A. G. (2005) Buku Ajar Fundamental Keperawatan, Konsep, Proses dan Praktek (edisi 4). Jakarta : Penerbit Buku Kedokteran EGC.

Perry, A. G., \& Potter, P. A. (2009). Potter and perry's fundamentals of nursing Australian version. (J. Crips \& C. Taylor, Eds.) ( $\left.3^{\text {rd }} \mathrm{ed}\right)$. Australian : mosby Elsevier Australia.

Potter, P. A., \& Perry, A. G., (2010). Fundamental of nursing. Buku 1, edisi 7. Jakarta : Salemba Medika.

Potter, P. A., \& Perry, A. G., (2013). Fundamentals of nursing. $\left(8^{\text {th }} \mathrm{ed}\right)$. Elsevier. 


